\title{
Design and Performance Evaluation of 0.2 Tonne Maize Dual Layer Solar Dryer
}

\author{
Donald Oigbochie ${ }^{1}$, Samuel Omojola Ejiko ${ }^{2}$ \\ Senior Technologist, Mechanical Engineering, The Federal Polytechnic, Ado-Ekiti, Ekiti State, Nigeria ${ }^{1}$ \\ Senior Lecturer, Mechanical Engineering, The Federal Polytechnic, Ado-Ekiti, Ekiti State, Nigeria ${ }^{2}$
}

\begin{abstract}
The need to minimize wastage from agricultural produce cannot be over emphasized. as mechanisation is introduced to the agricultural sector gradually in developing nations, so the harvest yield is in the increase continuously, maize which is majorly seasonal produce, needs to be dried and stored to make it available during the non-harvesting period. the drying of grains for mechanized farmers requires the development of a medium-scale solar dryer of $231 \mathrm{~kg}$ grains of maize in a batch of two layers. A solar grain dryer, rectangular with a transparent top, which sizes is $1244 \mathrm{~mm}$ by $3988 \mathrm{~mm}$ by $1229 \mathrm{~mm}$ was designed and constructed of metal sheet, wood and glass. The evaluation of its performance was carried out in rural areas. The design is based on the achievable temperature of $50^{\circ} \mathrm{C}$ to $60^{\circ} \mathrm{C}$. The grain dryer capacity is $23 \mathrm{~kg} /$ day of maize. The recommendations for effective dryer maintenance were stated which are within the technical capability of local farmers.
\end{abstract}

Keywords: Chamber, Dryer, Layers, Maize, Performance, Solar and Wastage

\section{INTRODUCTION}

In many parts of the world there has been an increasing awareness that renewable energy has an important role to play in extending technology to the farmer in developing countries to increase their productivity [1]. Solar thermal technology is a technology that is rapidly gaining acceptance as an energy-saving measure in agriculture application. It is preferred to other alternative sources of energy such as wind, chemical and electricity, because it is abundant, inexhaustible, and non-polluting [2;3].

Solar grain dryers are used for drying grains such as maize, rice, beans and millet. A solar dryer makes use of sun rays as a source of energy for drying. Traditional drying, which is frequently done on the ground in the open air, is a widespread method used in developing countries because it is the simplest and cheapest method of conserving foodstuffs. Some of the disadvantages of open-air drying methods include exposure of the foodstuff to rain and dust, uncontrolled drying, exposure to direct sunlight which is undesirable for some foodstuffs, infestation by insects, and attack by animals [4]. In the early days of civilization, a man had set aside or stored a sufficient proportion of his agricultural products (grains) obtained during the growing season to feed on until the next harvest. This was easy because of the limited quantity being produced by the farmers to feed and have little to sell, with time and a gradual increase in global population, there was the need for more food to be produced to meet demand. This lead to the development of alternative methods of grain drying

The grain is harvested at the peak of the rainy season, making preservation difficult and causing most of the grains to perish [5]. This results in scarcity in the supply of grains which leads to subsequent hunger and malnutrition. Meanwhile grains are routinely seen dumped in villages and major cities during the peak of harvest. Therefore, it is necessary that grains are properly dried and stored to yield better quality grains \& ensures availability and viability [6]. Drying is a dual process of heat and mass transfer of moisture from the interior of the product to the surrounding air [7]. [8] stated that the term drying from the industrial standpoint is understood to represent the removal of liquid from a solid by thermal means. Drying also means the removal of water from a suspension or solution of a liquid [9]. [10] revealed that drying involves the abstraction of moisture from the product by heating and the passage of air mass around it to carry away the release vapour. It is a process of heat and mass (moisture) transfer. The process of heat transfer requires the application of hot ventilating air to the grain to evaporate the moisture by converting it into water vapour while the mass transfer involves the mixing of water vapour with the drying air and its eventual transportation outside the dryer [7]. It can also be defined as a process of moisture removal due to simultaneous heat and mass transfer [11].

In subsequent years, empirical research has been achieved on modern technology to produce high-quality seed. In this scientific technology, the use of solar drying has been introduced. Solar drying uses air and supplementary heat utilizing solar energy, according to [6] transferring of moisture content from grain surface to the air around is the first step in grain drying which is known as "constant rate period" and the movement of moisture content from the inside of the grain to corn surfaces which is also called the "falling rate period". The amount of moisture that can be removed from 
grain is depended upon the condition of the grain and the condition of the amount of air moving around the grain [12]. Solar drying has become accepted as a viable alternative for traditional open-air sun-drying method, grid-connected electricity-powered and energy-intensive mechanical post-harvest crop dryers $[13 ; 14 ; 15 ; 16 ; 17 ; 18]$. There is quite an array of designs and configurations from direct isolation, natural convection to indirect isolation, forced convection types. There is usually a preference for indirect solar dryers over direct types particularly for crops like fruits and vegetables, whose vitamins and minerals content can be destroyed by sunlight [19]. There is equally preference for natural convection dryers over forced convection types for rural applications where power supply is either not available or in short supply [20;21] because they do not require fans or blowers [22] since airflow is by buoyancy effect. They can be made from locally available materials and are therefore inexpensive to install and run.

$[16 ; 23 ; 24]$ stated that energy (power) requirement for fans employed in forced convection solar driers is relatively small and can be operated by photovoltaic modules or batteries independent of the grid. However, challenges of the installation cost of solar panels and recharging of batteries tip the scale toward natural convection systems for rural farmers.

The shortcoming with natural convection types of dryers, direct or indirect, is low airflow velocities which often result in low performance [25]. Air temperature would normally drop when it absorbs moisture causing an increase in the average density. This would result in more in high convection current within the dryer than airflow out of it. Airflow can stop or even be reversed if air density within the chamber equals that of outside air or drops below it [26; 27; 28; 29] have suggested and demonstrated that addition of heated chimneys can improve the effects of natural convection while [30] observed that heating air in chimneys can ensure that the air density is always lower inside the chimney than outside which aids airflow out of drier.

Present chimney designs consist of a vertical pipe painted matte black on the outside rising above the drier or, according to the design of [29], a glass cover making up the sun-facing part of the chimney and an absorber plate on the inside of the back facing the sun.The developed grain dryer requires that solar energy is admitted through a glasscovered wall onto an absorber located vertically in the back of the chimney. This heats the air flowing through it and/or above the drying chamber increasing airflow from bottom to the top.

\section{METHODOLOGY}

The solar grain dryer considered in this work is simple and cheap in construction. The product is placed on trays inside the glass-covered drying chamber as shown in Plate 1. Fig. 1 is the exploded view of the design drawing while Fig. 2 is the working diagram that reveals the dimensions of the frame. Solar radiation is thus not incident directly on the grain.

The research operational ideal includes:

$>$ Heat is absorbed by the black substance (Solar collector)

$>$ thermos phonic principle is used to achieve the drying aim:

$>$ Warm air is always lighter than cold air and,

$>$ Air flows from high pressure to low pressure.

Preheated air warmed during its flow through a low-pressure thermos phonic solar energy air heater, is ducted to the drying chamber to dry the product. The products are not subjected to direct sunshine, which implies avoiding localized heat damage [31].

The major material used is wood. The wood was constructed to form a rectangular box; it was cut into sizes to the required dimensions with a saw and was assembled with the use of nails. The transparent glass was then cut to the required dimension with the aid of a diamond cutting tool to form a rooftop shape; the glass was glued over the box which serves as a collector. Sheet metal was also measured to the required size and bent accordingly for the production of the drying tray.

\section{THE SOLAR GRAIN DRYER COMPONENTS}

The Collector: The solar energy collector consists of a transparent roof, the absorber tray, and the reflector. The transparent roof was made up of a glass of $4 \mathrm{~mm}$ thickness. The roof is removable to allow for easy removal of the reflector. The glass roof was used to reduce heat loss from the absorber. The trays were painted black and used as absorbers which are made from a 16gauge sheet metal, with a dimension of $1239 \mathrm{~mm}$ by $1219 \mathrm{~mm}$, the trays were painted black and used as absorbers. The trays were perforated with holes of $5 \mathrm{~mm}$ for the passage of the rising warm (heated) air from the bottom.

Drying Chamber: It is the main part of the dryer, where the products are being placed and get dried there. It consists of a six-layer of shelves made up of coated steel material and perforated with tiny holes When the dried air passes through the layers, the product place inside the dryer gets dried. The drying chamber is a rectangular box of $1239 \mathrm{~mm}$ by 3962 $\mathrm{mm}$ by $1219 \mathrm{~mm}$.

Tray: The average tray carrying capacity of the dryer is estimated at $55 \mathrm{~kg}$ per tray for the dual-layer. 


\section{International Advanced Research Journal in Science, Engineering and Technology}

Vol. 7, Issue 5, May 2020

\section{DESIGN CONSIDERATIONS AND ANALYSIS}

The solar dryer has the shape of a home cabinet with a transparent top as shown in Fig. 3. It is provided with air inlet and outlet holes at the bottom and top respectively. The outlet vent is at a higher level. The vents have fix covers which control air inflow and outflow. The source of air is a natural flow and forced flow (Bellow).Maize grain was used as a case study to evaluate the performance of the solar grain dryer. Maize, also referred is corn with the scientific name of (Zea Mays), is a valuable crop. It is a cereal grain widely grown for food and livestock feed. Corn has been of importance in the life of people since 4500 years ago [5].

The dryer consist of frame and trays made of metal, the cover door, side and bottom made of wood. Wood has good insulation properties, is cheap and available locally. The trays plates were constructed from $3 \mathrm{~mm}$ gauge mild steel because of the strength and durability of mild steel. It is also relatively cheap and available locally. $5 \mathrm{~mm}$ thin plane glass sheets will be employed as glazing cover for the two solar air heaters. The thickness is sufficient for rigidity and strength and should be light enough to be borne by the wooden housing and frame of the heater and drying chamber. It is also readily available.

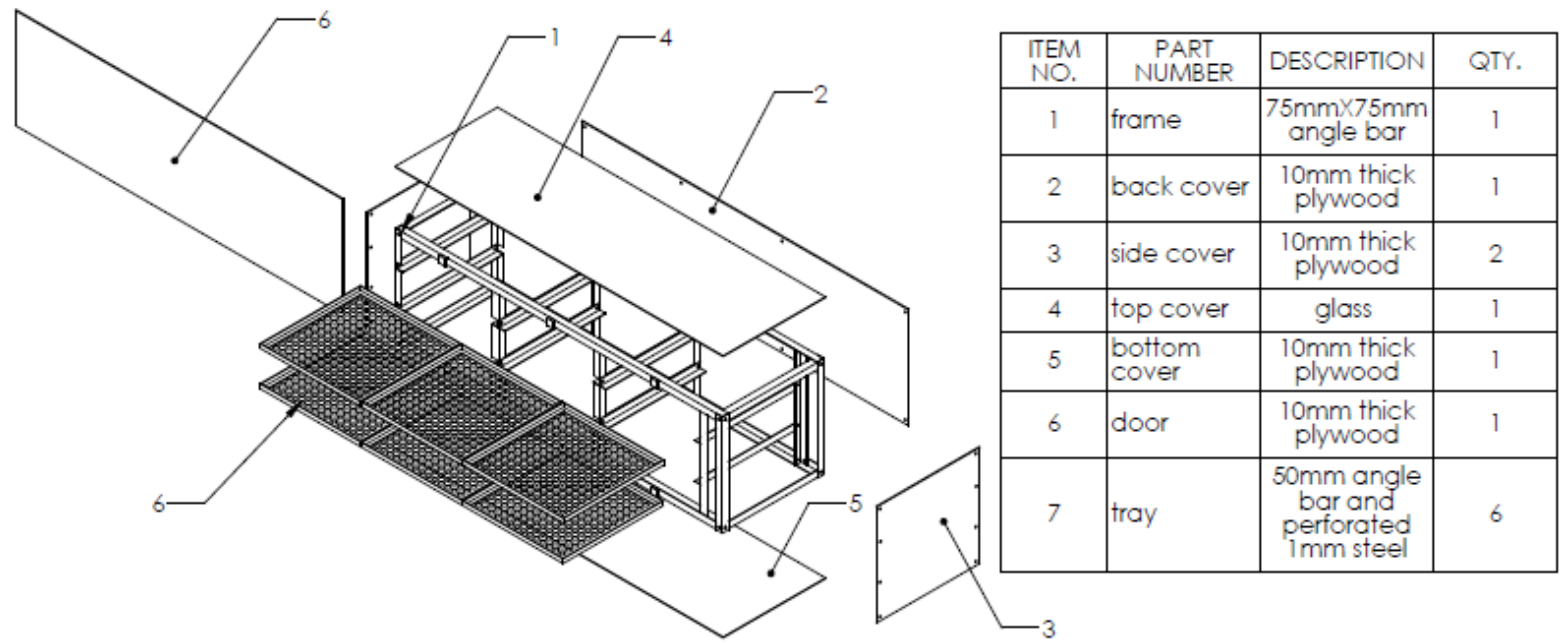

Fig. 1: Exploded Diagram of the Solar Dryer

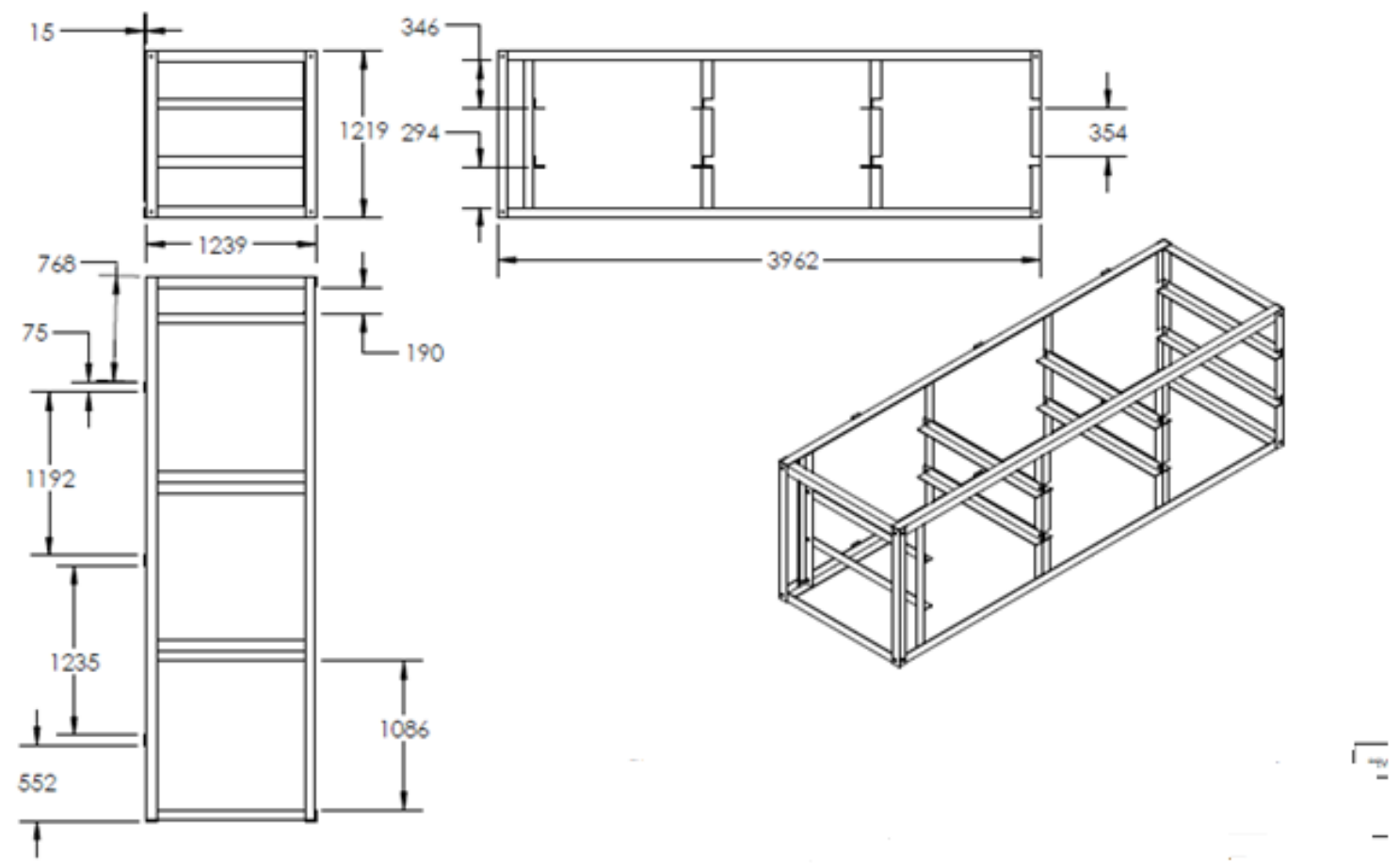

Fig. 2: Solar Dryer Frame Working Diagram 


\section{International Advanced Research Journal in Science, Engineering and Technology}

Vol. 7, Issue 5, May 2020

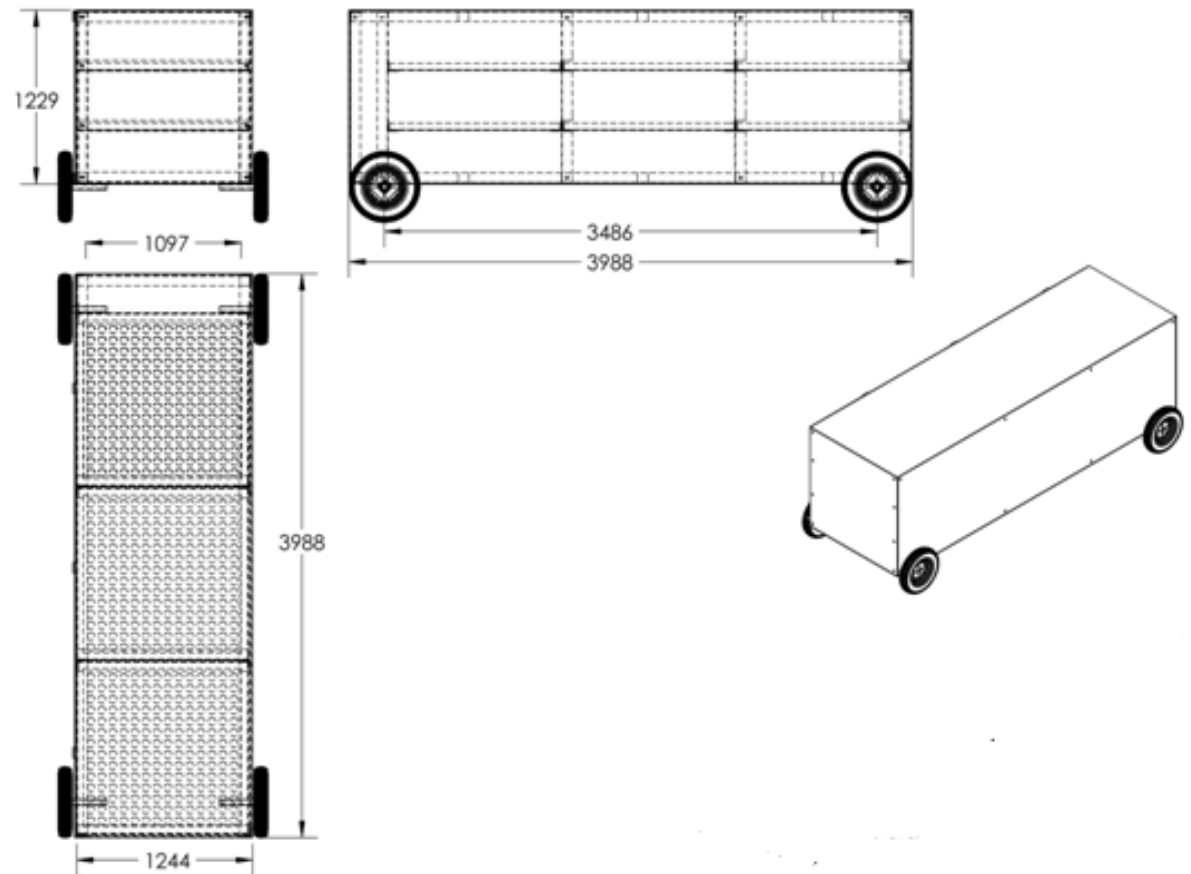

Fig. 3: Assembly Maize Dryer Orthographic and Isometric Drawing

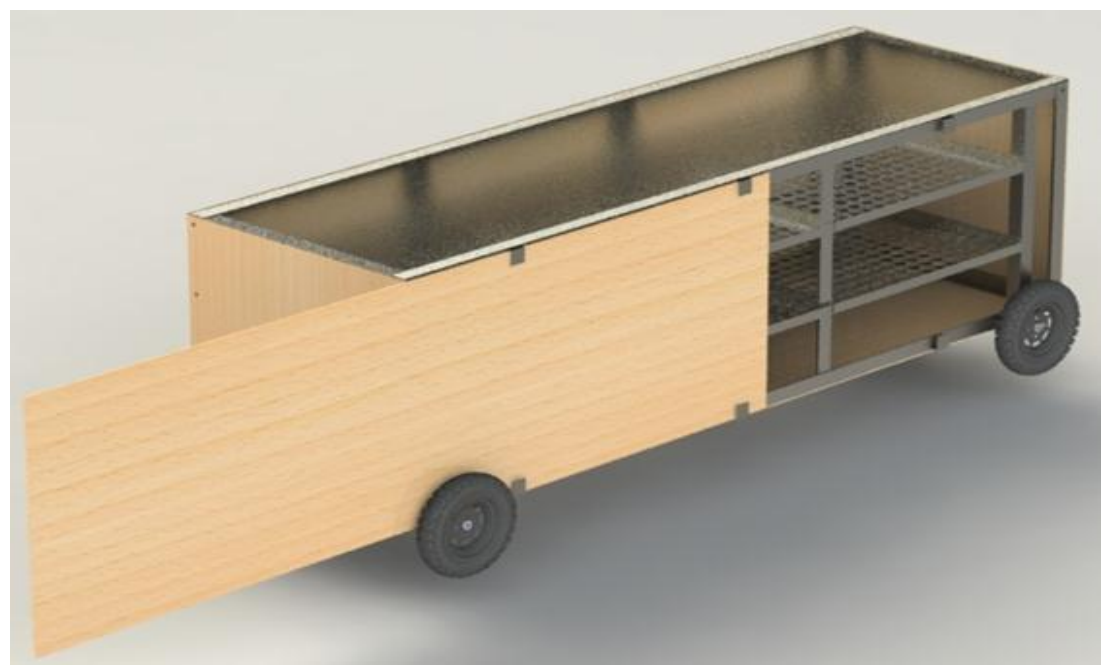

Plate 1: Developed Maize Solar Dryer

\section{Design Calculations}

The intensity of radiation, the volume of air, ambient temperature, the quantity of moisture removed from grains and the collector efficiency are fundamental that are establish to ascertain the conformity of the developed machine.

$I\left(\mathrm{~W} / \mathrm{m}^{2}\right)$ is the intensity of radiation incident on a flat surface and $t(\mathrm{~s})$ is the total time required to dry grain to desired moisture content, $T_{a m b}(\mathrm{~K})$ being ambient temperature while $T_{o}(\mathrm{~K})$ is the temperature of the air leaving primary air heater and $C_{p a}$ is the specific heat capacity of air.

$\dot{M}_{a}(\mathrm{~kg} / \mathrm{h})$, the mass flow rate of air required for drying crop over time $t(\mathrm{~s})$ is given in Equation 1 .

$$
\dot{M}_{a}=\frac{\rho_{a} V_{a}}{t}
$$

$\rho_{a}$ is the density of air at the outlet to drying chamber and $P_{\mathrm{a}}\left(\mathrm{N} / \mathrm{m}^{2}\right)$ is the partial pressure of dry air in the atmosphere. $V_{a}\left(\mathrm{~m}^{3}\right)$, the total volume of air required to reduce moisture content is obtained from Equation 2 as given by [32].

$$
V_{a}=\frac{M_{g} L_{m} R_{w} T_{a m b}}{C_{p a} P_{a}\left(T_{o}-T_{f}\right)}
$$

$M_{g}(\mathrm{~kg})$ is the initial mass of crop to be dried while $m_{i}$ and $m_{f}$ are crop moisture contents (on wet basis) before and after drying.

$T_{f}$ is the temperature of the air leaving the drying bed and is given in Equation 3.

$$
T_{f}=T_{a m b}+0.25\left(T_{o}-T_{a m b}\right)
$$




\section{International Advanced Research Journal in Science, Engineering and Technology}

Vol. 7, Issue 5, May 2020

$L_{m}$, (in $\mathrm{J} / \mathrm{kg}$ ) latent heat of evaporation of moisture to be removed from grains in equation 4 can be estimated from the expression suggested by [33] as described in Equation 4.

$$
L_{m}=R_{w} T_{b} T_{c} \frac{\left(T_{c}-T_{a v}\right)^{0.38}}{\left(T_{c}-T_{b}\right)^{1.38}} \ln \frac{P_{c}}{10^{5}}
$$

$R_{w}(\mathrm{~J} / \mathrm{kgK})$ is the gas constant for water vapour while $T_{b}$ and $T_{c}$ boiling and critical temperatures of water respectively and $P_{c}$ is critical pressure of water.

The average temperature attained by-product during the drying process, $T_{a v}$, is equal to the weighted mean of the temperatures of the air entering and leaving the dryer as stated in Equation 5.

$$
T_{a v}=0.25\left(3 T_{o}+T_{a m b}\right)
$$

The total quantity of moisture to be removed from the crop to reduce moisture content $\left(M_{m}\right)$, in $\mathrm{kg}$, is dependent on the crop and can be found from the expression suggested by [32] in Equation 6.

$$
M_{m}=\frac{M_{g}\left(m_{i}-m_{f}\right)}{1-m_{f}}
$$

The effective surface area of a primary air heater $\left(A_{c}\right),\left(\mathrm{m}^{2}\right)$ can be determined from collector efficiency, $\eta_{c}$, given in [34] in Equation 7.

$$
\eta_{d}=\frac{3600 \times 10^{-6} \dot{M}_{a} C_{p a}\left(T_{o}-T_{a m b}\right)}{A_{c} I} \times 100
$$

Using the values below which assumes a poorly efficient solar air heater, $12.5 \%$, area of primary air heater is equal to $2.42 \mathrm{~m}^{2}$ in a dual-layer arrangement.

$M_{g}=231 \mathrm{~kg}(0.23$ tonne of wet maize $)$

$m_{i}=0.22$

$m_{f}=0.13$

$T_{a m b}=25^{\circ} \mathrm{C}=298 \mathrm{~K}$

$T_{o}=60^{\circ} \mathrm{C}$

$T_{c}=404^{\circ} \mathrm{C}=677 \mathrm{~K}$

$T_{b}=100^{\circ} \mathrm{C}=373 \mathrm{~K}$

$R_{w}=461.5 \mathrm{~J} / \mathrm{kgK}$

$P_{c}=22064 \mathrm{KN} / \mathrm{m}^{2}$

$P_{\mathrm{a}}=101325 \mathrm{~N} / \mathrm{m}^{2}$

$I=400 \mathrm{~W} / \mathrm{m}^{2}$ (average solar intensity for Ado Ekiti)

$\rho_{a}=1.059 \mathrm{~kg} / \mathrm{m}^{3}$

$C_{p a}=1007 \mathrm{~J} / \mathrm{kgK}$

$\eta=0.125$

A two-layer drying bed arrangement recommended in [32] therefore the "upper bed is $0.8 \mathrm{~m}$ above the lower bed was proposed.

Conceptual Framework: The solar air heaters absorb solar energy through absorber (air-heating) plates. A secondary air heater absorber plate is perforated to allow airflow through an absorber plate. Air flows through primary air heater air passage, absorbs heat through absorber plate which is heated by the sun and flows into the dryer and over crops /grains on drying beds. Water moisture is removed from crops on drying trays by the air which afterward exits through secondary air heaters absorber plate perforations and the chimney. The density of air within the dryer tends to increase a little after it has absorbed moisture. This condition could result in lower airflow velocities due to the creation of a convection current within a dryer or even a backward flow with air entering through the chimney. As air from the top of dryer exits a vacuum would be created which would draw air from the bottom and through the primary dryer to the top. Access to drying chamber for loading and unloading of crops and inspection will be provided through a door at one of the sides.

\section{Solar Dryer Design Considerations:}

The following point has been considered in the design of the natural convection solar dryer system:

a) The amount of moisture to be removed from a given quantity of wet mango.

b) The quantity of air needed for drying.

(a) The volume of the drying compartment

The volume of the drying compartment was obtained using Equation 8 as given by [35].

$\mathrm{V}_{\mathrm{C}}=$ Length $\mathrm{x}$ Breadth $\mathrm{x}$ Height

$\mathrm{V}_{\mathrm{C}}=1035 \times 365 \times 463=174909825 \mathrm{~mm}^{3}$

\section{(b) Determination of Capacity of Tray}

The three perpendicular of maize is:

Major diameter $(\mathrm{a})=7.01 \mathrm{~mm}$ 


\section{International Advanced Research Journal in Science, Engineering and Technology}

Vol. 7, Issue 5, May 2020

Minor diameter $(b)=6.34 \mathrm{~mm}$

Intermediate diameter $(\mathrm{c})=4.30 \mathrm{~mm}$

Geometric mean $=(\mathrm{abc}) \frac{1}{3}=(7.01 \times 6.35 \times 4.30) \frac{1}{3}$

Geometric mean $=5.76 \mathrm{~mm}$

Project area $=\frac{\pi d^{2}}{4}=\frac{3.142 \times 33.178}{4}=\frac{104.2440192}{4}$

Project area $=26.06 \mathrm{~mm}^{2}$

Area of tray

Length $=1239 \mathrm{~mm}$

Breath $=1219 \mathrm{~mm}$

Height $=45 \mathrm{~mm}$

Area $=$ length $\times$ breath $=1239 \times 1219$

Area $=1,510,341 \mathrm{~mm}^{2}$

Capacity of the tray $=\frac{\text { areaofthetray }}{\text { projectedareaofmaize }}=\frac{1510341}{26.06}$

Capacity of tray $=57,956.3$ grains

Estimated quantity of maize $=$ Tray capacity $\times 6$

$57,956.3 \times 6=347,738$ grains

where

1cup of 90 percent moisture content of maize contains 418 grains

Number of cups/layer of the 6 trays

$=\frac{347,738}{418}=832 \mathrm{cups}$

Number of bowls $=83.2$ bowls/layer

Two layers therefore implies 166.4 bowls

Where 72 bowls $=100 \mathrm{~kg}$ maize

166.4 bowls $=\frac{166.4}{72} \times \frac{100}{1}=231 \mathrm{~kg}$.

The design capacity $=231 \mathrm{~kg}$ maize/dual layer

(c) Moisture Content

The amount of moisture to be removed from a given quantity of wet grain is determined at this stage. It is the moisture content that is suitable for safe storage during a specified period. The amount of moisture to be removed from the product, $\mathrm{Mw}$ in $\mathrm{kg}$ was calculated using Equation 10 as given by [36].

Moisture content $=\quad \frac{M_{W}-M_{D}}{M_{W}} \times 100$

where,

$\mathrm{M}_{\mathrm{W}}=$ Mass of wet grain,

$\mathrm{M}_{\mathrm{D}}=$ Mass of dry grain

\section{RESULT AND DISCUSSIONS}

The solar dryer was fabricated as shown in plate $1.1 \mathrm{~kg}$ of fresh maize was arranged on the dryer tray in a single layer to avoid moisture being trapped in the lower layer with the solar dryer door closed. The weight and the temperature of the maize grain were measured and recorded at different time intervals of 3hours starting from 9am to 6pm as given in Table 1 which shows that increase in the ambient temperature implies an increase in the solar dryer.

Table 1: Cup Sample Collection Results

\begin{tabular}{|c|c|c|c|c|}
\hline Sample Label & Num. of Wet Grains & Weight of Wet Grains & Weight of Dry Grains & Increase in Amb. Temp. \\
\hline A & 419 & 0.3 & 0.25 & $+25^{\circ} \mathrm{C}$ \\
\hline B & 415 & 0.3 & 0.25 & $+25^{\circ} \mathrm{C}$ \\
\hline C & 417 & 0.3 & 0.25 & $+25^{\circ} \mathrm{C}$ \\
\hline D & 420 & 0.32 & 0.26 & $+25^{\circ} \mathrm{C}$ \\
\hline E & 419 & 0.3 & 0.25 & $+25^{\circ} \mathrm{C}$ \\
\hline
\end{tabular}

$\mathrm{T}_{\mathrm{A}}=$ Ambient Temperature ${ }^{\circ} \mathrm{C}$

$\left(\mathrm{T}_{\text {DUCT }}\right)=$ Outlet temperature from Collector

Maize weight $=231 \mathrm{~kg}$

Moisture content: 


\section{International Advanced Research Journal in Science, Engineering and Technology}

Vol. 7, Issue 5, May 2020

$M_{w}=231 \mathrm{~kg}$ Mass of sample before drying

$M_{D}=189.5 \mathrm{~kg}$ mass of the sample after drying

$\frac{231-189.5}{231} \times \frac{100}{1}=17.6 \%$

\section{Dryer Efficiency}

The system efficiency indicates the overall thermal performance of a drying system including the efficiency of a solar collector, the drying chamber and any other supplement add to the system. The dryer efficiency is estimated using [37] equation.

Dryer efficiency $\%=\frac{\text { workoutput }}{\text { workinput }} \times 100$

Where

Work output $=$ final mass of the grain after drying

Work input $=$ initial mass of the grain before drying

Initial mass of grain after drying $=189.5 \mathrm{~kg}$

Initial mass of grain before drying $=230 \mathrm{~kg}$

Dryer Efficiency

$$
=\frac{\text { workoutput }}{\text { workinput }} \times \frac{100}{1} \text { initial mass before drying }
$$

$\frac{189.5 \times 100}{230}=82.4 \%$

\section{CONCLUSION}

A solar grain dryer was developed and its performance was tested and evaluated with maize grains, it was made of wood, metal sheet and glass with a capacity of $231 \mathrm{~kg}$. a temperature of $60^{\circ} \mathrm{C}$ was obtained in the solar energy, while a temperature of $35^{\circ} \mathrm{C}$ was recorded in the direct sun drying. The increase in temperature of the solar dryer increased the performance of the drying over that of direct sun dryer and it could generate higher temperature and consequently lower relative humidity which are both conducive to improved drying rates and to lower final moisture contents of the dried crops.

\section{Recommendations}

The following recommendations should be observed for the effective maintenance of the dryer, the transparent glass and cover of the solar collector should be clean regularly to ensure the dust does not remain on it. Secondly, the drying chamber should be opened slightly by adjusting air inlet accordingly to raise the chamber temperature to equilibrium by sliding it and lastly, the absorber plate should be repainted every quarter.

\section{REFERENCES}

[1]. Waewsak, J.Chindaruksa, S.and Punlek, C. (2006)."A Mathematical Modeling Study of Hot Air Drying for Some Agricultural Products" Thammasat Int. J. Sci. Technol., 11(1): p14-20.

[2]. Akinola, A. O. and Fapetu, O. P. (2006).“Exergetic Analysis of a Mixed-Mode Solar Dryer”, J. Eng. Appl. Sci., 1: Pp 205-210.

[3]. Akinola, O. A.Akinyemi, A. A.and Bolaji, B. O. (2006)."Evaluation of Traditional and Solar Fish Drying Systems towards Enhancing Fish Storage and Preservation in Nigeria", J. Fish. Int., Pak., 1(4), Pp 44-49.

[4]. Madhlopa, A., Jones, S. A. and Kalenga S. J. D. (2002). "A Solar Air Heater With Composite Absorber Systems for Food Dehydration". Renewable Energy, p 27-37.

[5]. Kiniry, J. R. Tischler, W. Rosenthal, D and.Gerik, T. J. (1992). "Non Structural Carbohydrate Utilization by Sorgtium and Maize shaded during Growth", Crop Science 32: Pp131-137

[6]. Ayodele, O. R.Oluwaleye, I. O. and Adepo,S. O. (2016)."Design and Construction of Electric Corn Dryer" Journal of Multi-Disciplinary Engg Science and Technology (JMEST) Vol. 3 Issue 3.

[7]. Hall, C.W. (1980). "Drying and Storage of Agriculture Crops", AVI Publishing Company, Inc. Westport, Connecticut, U.S.A, P 134.

[8]. Bennett, A. S. Bern, C. J. Richard, T. L.and Anex, R. P.(2007). "Corn Grain Drying Using Corn Stover combustion and CHP systems", Transaction of the ASABE. 50(6): Pp2161-2170.

[9]. Adzimah, K.S. and Seckley, E. (2009). "Improvement on the Design of a Cabinet Grain Dryer", America Journal of Engineering and Applied Science 2 (1). Pp $217-228$.

[10]. McLean, K. A. (1980). "Drying and Storage of Combinable Crops", Farm press Ltd, Ipswich, Suffolk, United Kingdom, p 37

[11]. Ertekin, C. and Yaldiz, O.(2004). "Drying Of Egg- Plant and Selection of a Suitable Thin Layer Drying Model”,J. Food Engineering. 63: p349-359

[12]. Brown, R.B.. Fulford,G.N., Daynard, T. B. Meiering A.G. and Otten L. (1979). "Effect of Drying on Grain Cuality", Cereal Chem. 56(6): Pp529-532. 


\section{International Advanced Research Journal in Science, Engineering and Technology}

Vol. 7, Issue 5, May 2020

[13]. Banouta, J., Ehla, P., Havlikb, J., Lojkac, B., Polesnyc, Z. and Vernerd, V. (2011). Design and Performance Evaluation of a Double-Pass Solar Drier for Drying of Red Chilli (Capsicum Annum L). Solar Energy, 85, 506-51.

[14]. Murthy, M. V. (2009). A Review of New Technologies, Models and Experimental Investigations of Solar Driers. Renewable and Sustainable Energy Reviews, 13(4), 835-844.

[15]. Bala, B., Mondol, M., Biswas, B., Das Chowdury, B. and Janjai, S. (2003). Solar Drying of Pineapple Using Solar Tunnel Drier. Renewable Energy, 28, 183-190.

[16]. Hossain, M., and Bala, B. (2007). Drying of Hot Chilli Using Solar Tunnel Drier. Solar Energy, 81, 85-92

[17]. Mekhilefa, S., Saidurb, R. and Safari, A. (2011). A Review on Solar Energy use in Industries. Renewable and Sustainable Energy Reviews, 15(4), 1777-1790.

[18]. Xingxing, Z., Xudong, Z., Stefan, S., Jihuan, X. and Xiaotong, Y. (2012). Review of R\&D Progress and Practical Application of the Solar Photovoltaic/Thermal (PV/T) Technologies. Renewable and Sustainable Energy Reviews, 16(1), 599-617.

[19]. Abur, B. T., Dan-Dakouta, H., and Egbo, G. (2014). Food Security: Solar Dryers And Effective Food Preservation. International Journal of Advanced Engineering Research and Studies, 3(2), 166-171.

[20]. Eltawil, M. A., Abou Zaher, S. E., and El-Hadad, W. Z. (2012). Solar-Wind Ventilation to Enhance the Cabinet Dryer Performance for Medicinal Herbs and Horticultural Products. Agricultural Engineering International, 14(4), 56-74.

[21]. Pangavhane, D., Sawhney, R. L., and Sarsavadia, P. N. (2002). Design, Development and Performance Testing of a New Natural Convection Solar Dryer. Energy, 27, 579-590.

[22]. Forson, F. K. (1999). Modelling and Experimental Investigation of a Mixed-Mode Natural Convection Solar Crop Dryer. Leicester, UK: PhD Thesis, De Montfort University.

[23]. Bala, B. K., Ashraf, M. A., Uddin, M. A., and Janjai, S. (2005). Experimentaland Neural Network Prediction of the Performance of a Solar Tunnel Drier for Drying Jackfruit Bulbs and Leather. Journal of Food Process Engineering, 28(6), 552-566.

[24]. Chen, H., Hernandez, C., and Huang, T. (2005). A Study of the Drying Effect on Lemons Lices Using a Closed-Type Solar Dryer. Solar Energy, 78, 97-103.

[25]. Ekechukwu, O. V. (1999). Review of Solar-Energy Drying Systems II: An Overview of Solar Drying Technology. Energy Conversion and Management, 40(6), 615-655.

[26]. Chen, Z. D., Bandopadhayay, P., Halldorsson, J., Byrjalsen, C., Heiselberg, P., and Li, Y. (2003). An Experimental Investigation of a Solar Chimney Model with Uniform Wall Heat Flux. Building and Environment, 38(7), 893-906.

[27]. Eltawil, M. A., and Imara., Z. M. (2005). Utilization of Photovoltaic Array in a Multi-Tray Fruits Drying System for Rural Areas. journal of Agricultural Engineering, 22(4), 820-845.

[28]. Ferreira, A. G., Maia, C. B., Cortez, M. B., and Valle, R. M. (2008). Technical Feasibility Assessment of a Solar Chimney for Food Drying. Solar Energy, 82(3), 198-205.

[29]. Afriyie, J. K., Rajakaruna, H., Nazha, M. A., and Forson, F. K. (2011). Simulation and Optimisation of the Ventilation in a Chimney-Dependent Solar Crop Dryer. Solar Energy, 87(7), 1560-1573

[30]. Afriyie, J. K., Nazha, M. A., Rajakaruna, H., and Forson, F. K. (2009). Experimental Investigations of a Chimney-Dependent Solar Crop Dryer. Renewable Energy, 34(1), 217-222.

Al-Juamily, K. E., Khalifa, A. J., and Yassen, T. A. (2007). Testing of the Performance of a Fruit and Vegetable Solar Drying System in Iraq. Desalination, 209(1-3), 163-170

[31]. Sandeep, P. Satish, K. S. Sunil, Y. Asim, K. T. and Ravi, N.(2013). "Design, Construction and Testing of Solar Dryer with Roughened Surface Solar Air Heater", International Journal of Innovative Research in Engineering \& Science, issue 2 Volume 7.

[32]. Forson, F. K., Nazha, M. A., Akuffo, F. O., \& Rajakaruna, H. (2007). Design of Mixed-Mode Natural Conbection Solar Crop Dryers: Application of Principles and Rules of Thumb. Renewable Energy, 32(4), 2306-2319.

[33]. Liley, P. E., and Gambill, W. R. (1973). Physical and Chemical Data. In R. H. Perry, \& C. H. Chilton, Chemical Engineers' Handbook (Vol. 5th Edition). New York: McGraw-Hill Book Company.

[34]. Maiti, S., Patel, P., Vyas, K., Eswaran, K. and Ghosh, P. K. (2011). Performance Evaluation of a Small Scale Indirect Solar Dryer With Static Reflectors During Non-Summer Months in The Saurashtra Region of Western India. Solar Energy, 85, $2686-2696$.

[35]. Ejiko S. O., Oigbochie D. and Emmanuel A. A. (2018): "Design of A Semi Mechanize Gari Fryer" IOSR Journal of Mechanical and Civil Engineering (IOSR-JMCE) Volume 15, Issue 2 Ver. IV pp 23-30 www.iosrjournals.org

[36]. Brooker, D.B. Baker-Arkema, F.W. and Hall C.W. (1973). "Drying Cereal Grains", The Av1 Publishing coy; Inc. West port Connecticut USA,P. 256.

[37]. Augustus, L. M. Kumar, S. Bhattacharya, S. C.(2002), "A Comprehensive Procedure for Performance Evaluation of Solar Food Dryers", Renewable and Sustainable Energy Reviews, 6 (4), Pp 367-393.

\section{BIOGRPHIES}

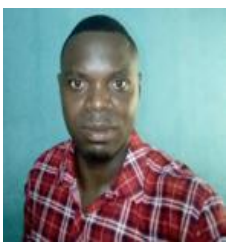

Donald Oigbochie is a Senior Technologist in the Department of Mechanical Engineering, The Federal Polytechnic, Ado=Ekiti, Ekiti State, Nigeria. He holds a Higher National Diploma in Mechanical Engineering. He is a member of National Association of Engineering Technologist (NATE). His research interests are in the areas of Renewable energy, Machine design and Production Engineering.

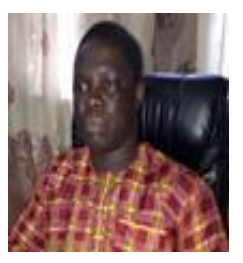

Samuel Omojola Ejiko is a Senior Lecturer in the Department of Mechanical Engineering, The Federal Polytechnic, Ado-Ekiti, Ekiti State, Nigeria. He holds a Doctor of Philosophy (Ph. D) degree in Mechanical Engineering. He is a member of many professional societies both national and international. The research interests are in the areas of Renewable energy, Machine design, Mechatronics, Industrial and Production Engineering. 